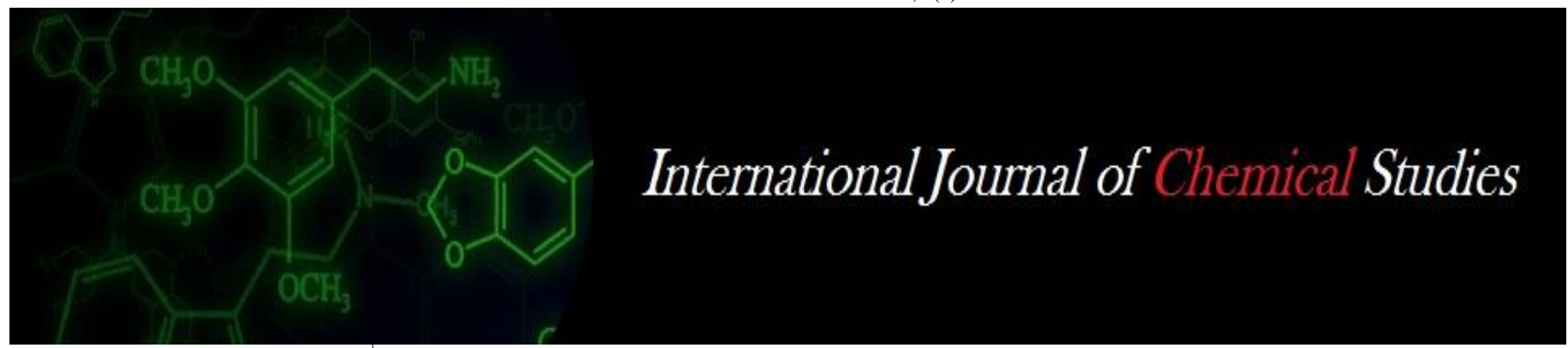

P-ISSN: 2349-8528

E-ISSN: 2321-4902

IJCS 2020; 8(1): 2483-2486

(C) 2020 IJCS

Received: 07-11-2019

Accepted: 09-12-2019

Basavanneppa MA

Agricultural Research Station,

Siruguppa, Karnataka, India

Ashok Kumar Gaddi

Agricultural Research Station,

Siruguppa, Karnataka, India
Corresponding Author: Basavanneppa MA

Agricultural Research Station,

Siruguppa, Karnataka, India

\section{Productivity and profitability as influenced by rice based cropping systems in Tunga Bhadra project area of Karnataka}

\section{Basavanneppa MA and Ashok Kumar Gaddi}

DOI: https://doi.org/10.22271/chemi.2020.v8.i1al.8641

\begin{abstract}
A field experiment under All India Coordinated Research Project was conducted for four years (2015-16 to 2018-19) in irrigated condition at Agricultural Research Station, Siruguppa, University of Agricultural Sciences (UAS), Raichur, Karnataka, India, to study the productivity and profitability of cropping system as influenced by rice based cropping system in Tunga Bhadra Project area of Karnataka on deep black soil. The experiment consisted of ten cropping systems and laid out in completely randomized block design with three replications. The results showed that, growing of rice followed by ridge gourd (Kharifsummer) recorded significantly higher rice equivalent yield (11338 kg/ha), gross return (Rs.213355/ha), net return (Rs.142691/ha), BC ratio (3.08), system productivity $(31.07 \mathrm{~kg} / \mathrm{ha} /$ day) and system profitability ( $537.54 \mathrm{Rs} / \mathrm{ha} /$ day) compared to other cropping systems. Whereas rice followed by beans cropping system registered significantly lowest rice equivalent yield, gross returns, net returns, BC ratio, system productivity and system profitability when compared to other cropping systems tested under the study.
\end{abstract}

Keywords: Cropping system, rice equivalent yield, gross returns, net returns, $\mathrm{BC}$ ratio

\section{Introduction}

Rice followed by rice is the most predominant cropping system in the deep and shallow black soil of Tungabhadra Project Area of Karnataka, India. Continuous cultivation of rice for longer periods with low system productivity, and often with poor crop management practices, led to loss in soil fertility due to emergence of multiple nutrient deficiency (Dwivedi et al., 2001) ${ }^{\text {[2] }}$ and deterioration of soil physical properties, and decline in factor productivity and crop yields in high productivity areas (Yadav, 2002) ${ }^{[12]}$.

Diversification and intensification of rice-based system to increase productivity per unit resource is very pertinent. Crop diversification shows lot of promises in alleviating these problems besides, fulfilling basic needs for cereals, pulses, oilseeds and vegetables and, regulating farm income, withstanding weather aberrations, controlling price fluctuation, ensuring balanced food security, preservation of natural resources, minimise the chemical fertilizer and pesticide loads, ensuring environmental safety and creating employment opportunity (Gill and Ahlawat, 2006) ${ }^{[3]}$. Crop diversification has been recognized as an effective strategy for achieving the objectives of food security, nutrition security, income growth, poverty alleviation, creation of employment opportunities, and judicious use of land and water resources, sustainable agricultural development and environmental improvement (Hedge et al., 2003) ${ }^{[5]}$. The crop diversification may enhance profitability, reduce pests, spread out labour more uniformly, reduce risks from aberrant weather by different planting and harvesting times and source of high value products from new crops (Reddy and Suresh, 2009) ${ }^{[8]}$. Rice being the staple food of people, hence, rice cannot be replaced with other crops during kharif season. The only option left is to identify suitable crops for rabi/summer seasons for non availability/scarcity of water due to less storage capacity in the reservoirs coupled with low water availability for the tail end farmers in the command area it is more so with TBP. Growing of crops such as vegetables, pulses and oilseeds during summer is an alternative approach for realizing higher productivity and profitability. Moreover, growing non paddy crops during summer has a special reference for efficient utilization of irrigation water, labour and other resources for higher productivity, profitability and food security. 
There is need to evaluate the possibilities of replacing summer rice with other suitable upland crops and include summer season crops for higher productivity. Similarly, there are opportunities to include grain legumes and vegetables during summer season.

The demand for vegetable crops has increased enormously leading to sharp increase in their prices and it has been the dominant factor for high inflationary pressure in Indian economy during recent years. Inclusion of crops like oilseeds, pulses, vegetables and fodder crops will improve the economic condition of small and marginal farmers owing to higher price and/or higher volume of their main and byproducts (Sharma et al., 2007) ${ }^{[9]}$. Hence, efforts are being made to promote diversification of rice - based cropping sequence in this area of country with vegetable crops for sustaining the productivity and to meet out demand for vegetables. Therefore, the present investigation was carried out to find out most productive, resource-use-efficient and remunerative cropping system for this region.

\section{Material and Methods}

An AICRP experiment was conducted for four years (2015-16 to 2018-19) under irrigated condition during 2016-17 to find out alternative cropping system for existing rice - rice system in TBP area at Agricultural Research Station, Siruguppa. The experiment consists of 10 treatments with rice grown in the kharif followed by different crops in the rabi and treatments were replicated thrice in the randomized complete block design. The experimental soil was deep black having slightly alkaline in $\mathrm{pH}(8.18)$ and low in soluble salt concentration $(0.38 \mathrm{dS} / \mathrm{m})$, medium in soil organic carbon content $(0.65 \%)$ and available phosphorus (11.3 kg/ha), low in available nitrogen (177 kg/ha) and rich in available Potassium (348 $\mathrm{kg} / \mathrm{ha}$ ). The treatments details, fertilizer dosage and varieties used in the experiment were given in Table 1 and 2. The fertilizers were applied in the form of urea, Diammonium phosphate (DAP) and muriate potash as per the recommended package of practice for each crop tested during both the seasons. The data on the yield parameters were recorded at harvest. The cost of inputs prevailing in the market at the time of their use was considered for calculation of the economics of different treatments. Net return per hectare was calculated by deducting the cost of cultivation from gross returns per hectare, gross returns was calculated by using the total income obtained from grain and straw yields and the benefit cost ratio was worked out as follows. Benefit cost ratio = Gross returns/Cost of cultivation. The rice equivalent yield was calculated by using the following formula (Verma and Mudgal, 1983) ${ }^{[11]}$,

YRC $(\mathrm{kg} / \mathrm{ha}) \times \operatorname{MPCC}(\mathrm{Rs} . / \mathrm{kg})+$ Yield of main crop $(\mathrm{kg} / \mathrm{ha})$ $\operatorname{REY}(\mathrm{kg} / \mathrm{ha})=$

Price of rice (Rs./kg)

Whereas, YRC $=$ Yield of rabi crop $\left(\mathrm{kg} \mathrm{ha}^{-1}\right), \mathrm{MPRC}=$ Market price of rabi crop (Rs. $\mathrm{kg}^{-1}$ ). The System Productivity (SP) for the cropping system was calculated as dividing the REY by number of days in a year and expressed in $\mathrm{kg} / \mathrm{ha} / \mathrm{day}$ and System profitability was calculated by dividing the Net Returns by number of days in a year i.e. 365 days. The plant samples were collected and subjected to chemical analysis. The grain and stover samples were analyzed for $\mathrm{N}$ by digesting sample with concentrated $\mathrm{H}_{2} \mathrm{SO}_{4}$ and the acid digested was distilled for $\mathrm{NH}_{3}$ by using $40 \% \mathrm{NaOH}$ and was estimated by titration against standard acid and phosphorus and potassium in the plant sample extracted by diacid were determined by vanodomolybidic yellow colour and flame photometry method, respectively (Jaiswal, 2004). MSTAT was used for statistical analysis of data and means were separated using critical difference $(\mathrm{CD})$ at $\mathrm{p}=0.05$ (Gomez and Gomez, 1984) ${ }^{[4]}$.

Table 1: Treatment details

\begin{tabular}{|c|c|c|c|c|}
\hline Treatments & Kharif & Rabi & Summer & Pre-monsoon \\
\hline 1 & Rice (BPT-5204) & - & Rice & Existing system \\
\hline 2 & Rice (SIRI-1253) & - & Ridge gourd (ZT and DS) & - \\
\hline 3 & Rice (SIRI-1253) + Sesbania (Incorporation after 55 \\
days) & - & Mustard & $\begin{array}{c}\text { Green gram } \\
\text { (Residue incorporation) }\end{array}$ \\
\hline 4 & Rice (SIRI-1253) & - & Beans & Sesbania incorporation \\
\hline 5 & Rice (SIRI-1253) & - & Siyazeera & Cesbania incorporation \\
\hline 6 & Rice (SIRI-1253) & Spinach & $\begin{array}{c}\text { Black gram } \\
\text { (Residue incorporation) }\end{array}$ & - \\
\hline 7 & Rice (GNV 10-89) & Methi & $\begin{array}{c}\text { Green gram (Residue } \\
\text { incorporation) }\end{array}$ & - \\
\hline 8 & Rice (GNV 10-89) & Rice (RASI) & Sesbania incorporation \\
\hline 9 & Rice (GNV 10-89) & $\begin{array}{c}\text { Sesbania } \\
\text { incorporation }\end{array}$ & Rice (RASI) & - \\
\hline 10 & Rice (GNV 10-89) & &
\end{tabular}

Table 2: Varieties and fertilizer used during experimentation

\begin{tabular}{|c|c|c|c|}
\hline Treatments & Crops & Varieties & Fertilizer doses (N, P, K kg/ha) \\
\hline 1. & Paddy & BPT-5204, Siri-1253 and GNV 10-89 & $150: 75: 75$ \\
\hline 2. & Ridge gourd & Jaipur long & $50: 50: 00$ \\
\hline 3. & Mustard & Varuna & $100: 60: 40$ \\
\hline 4. & Beans & Local & $60: 20: 20$ \\
\hline 5. & Siyazeera & Local & $50: 20: 20$ \\
\hline 6. & Coriander & Local & $75: 30: 30$ \\
\hline 7. & Blackgram & T9 & $12.5: 25: 00$ \\
\hline 8. & Green gram & Chinamung & $12.5: 25: 00$ \\
\hline 9. & Spinach & Local & $25: 00: 00$ \\
\hline 10. & Methi & Local & $100: 00: 00$ \\
\hline
\end{tabular}




\section{Results and Discussion \\ Grain and straw yield}

The pooled data over four years on grain yield were presented in Table 3. The grain yield of different crops during kharif/summer were significantly influenced by different cropping systems. Among the three rice varieties tested, SIRI1253 recorded higher yield $(6188 \mathrm{~kg} / \mathrm{ha})$ followed by GNV $10-89$ (5960 kg/ha). Similar results were also reported by Bastia et al (2008). However, BPT 5204 recorded least grain yield $(5122 \mathrm{~kg} / \mathrm{ha})$. During summer season the pooled data on yield indicated that ridge guard has recorded significantly higher pooled yield $(5244 \mathrm{~kg} / \mathrm{ha})$ compared to rest of the summer crops. In case of summer crops tested under study revealed that among the different crops Siyazeera $(420 \mathrm{~kg} / \mathrm{ha})$ recorded significantly lower grain yield compared to rest of the crops.

\section{Rice equivalent yield}

The pooled rice equivalent yield was worked out to identify the best cropping system among the different cropping systems evaluated and are presented in Table 4. The significantly higher rice equivalent yield $(11338 \mathrm{~kg} / \mathrm{ha})$ was noticed in rice followed by ridge gourd cropping system compared to other cropping systems. The higher rice equivalent in rice followed by ridge gourd was attributed to higher ridge gourd yield and higher price might be the reason to record the higher REY. The next best cropping system after rice - ridge gourd system was existing/traditional cropping system of rice followed by rice in Thunga Bhadra Project (TBP) area. Among the rice varieties tested, the higher REY (9694 kg/ha) was observed in $\mathrm{T}_{10}$ (Rice -rice variety GNV 10-89) and it was significantly superior to $T_{1}$ which includes traditional and fine quality variety of BPT 5204. The higher yield in GNV 10-89 than BPT 5204 might be due to higher yield. After these cropping systems, next best alternative rice cropping system is rice followed by beans $(7799 \mathrm{~kg} / \mathrm{ha})$ and rice followed by siyazeera $(7701 \mathrm{~kg} / \mathrm{ha})$ and these are significantly superior to T3 (6358 kg/ha) and T5 (6706 kg/ha). The low REY in these systems might have low yield potential. However, in the water scarcity situation in tail end user may be practiced these cropping systems. These results are conformity with the findings of Hegde et al. (2003) ${ }^{[5]}$.

Table 3: Pooled grain yield ( $\mathrm{kg} / \mathrm{ha})$ of crops as influenced by rice based Cropping system

\begin{tabular}{|c|c|c|c|c|c|c|c|c|c|c|}
\hline \multirow{2}{*}{ Treatments } & \multicolumn{2}{|c|}{$2015-16$} & \multicolumn{2}{|c|}{ 2016-17 } & \multicolumn{2}{|c|}{ 2017-18 } & \multicolumn{2}{|c|}{ 2018-19 } & \multicolumn{2}{|c|}{ Pooled } \\
\hline & Kharif & Summer & Kharif & Summer & Kharif & Summer & Kharif & Summer & Kharif & Summer \\
\hline $\mathrm{T}_{1}$ & 5176 & 3670 & 5109 & 3818 & 5208 & 3948 & 4993 & 4099 & 5122 & 3884 \\
\hline $\mathrm{T}_{2}$ & 5594 & $5788 *$ & 5886 & 5606 & 6035 & 4945 & 5415 & 4638 & 5732 & 5244 \\
\hline $\mathrm{T}_{3}$ & 6141 & 536 & 5473 & 495 & 5291 & 494 & 5374 & 471 & 5570 & 499 \\
\hline $\mathrm{T}_{4}$ & 6501 & 1546 & 5952 & 1483 & 5026 & 1393 & 5291 & 1400 & 5692 & 1455 \\
\hline $\mathrm{T}_{5}$ & 5652 & 485 & 6299 & 395 & 5671 & 390 & 5415 & 410 & 5759 & 420 \\
\hline $\mathrm{T}_{6}$ & 5112 & 746 & 7159 & 755 & 6531 & 680 & 5952 & 744 & 6188 & 731 \\
\hline $\mathrm{T}_{7}$ & 4867 & 1052 & 6200 & 1070 & 6696 & 955 & 6275 & 1056 & 6010 & 1033 \\
\hline $\mathrm{T}_{8}$ & 4726 & 744 & 6961 & 852 & 6035 & 807 & 6118 & 805 & 5960 & 802 \\
\hline $\mathrm{T}_{9}$ & 4469 & 3799 & 5374 & 3923 & 6035 & 4134 & 5787 & 4237 & 5416 & 4023 \\
\hline $\mathrm{T}_{10}$ & 4643 & 3901 & 5704 & 4048 & 6283 & 4070 & 5704 & 4232 & 5583 & 4063 \\
\hline SEm \pm & 172 & 87 & 185 & 86 & 256 & 53 & 231 & 76 & 211 & 69 \\
\hline $\mathrm{CD}(0.05)$ & 509 & 258 & 550 & 256 & 760 & 157 & 326 & 159 & 595 & 195 \\
\hline
\end{tabular}

*-Fresh weight

Table 4: Pooled rice equivalent, SP, GR, NR, B:C and S. Prof. as influenced by rice based cropping system

\begin{tabular}{|c|c|c|c|c|c|c|}
\hline Treatments & REY $(\mathbf{k g} / \mathbf{h a})$ & SP $(\mathbf{k g} / \mathbf{h a} / \mathbf{d a y})$ & GR $(\mathbf{R s} . / \mathbf{h a})$ & NR (Rs./ha) & B:C & S. Prod. (kg/ha/day) \\
\hline $\mathrm{T}_{1}$ & 8999 & 24.66 & 167881 & 90712 & 2.19 & 406.12 \\
\hline $\mathrm{T}_{2}$ & 11338 & 31.07 & 213355 & 142691 & 3.08 & 537.54 \\
\hline $\mathrm{T}_{3}$ & 6358 & 17.42 & 120483 & 62130 & 2.08 & 289.72 \\
\hline $\mathrm{T}_{4}$ & 7655 & 20.97 & 150469 & 86806 & 2.39 & 368.29 \\
\hline $\mathrm{T}_{5}$ & 6706 & 18.37 & 132938 & 71028 & 2.17 & 321.08 \\
\hline $\mathrm{T}_{6}$ & 7799 & 21.37 & 159064 & 97851 & 2.60 & 393.33 \\
\hline $\mathrm{T}_{7}$ & 7701 & 21.10 & 146605 & 87772 & 2.50 & 361.05 \\
\hline $\mathrm{T}_{8}$ & 7178 & 19.67 & 132980 & 73803 & 2.26 & 323.70 \\
\hline $\mathrm{T}_{9}$ & 9487 & 25.99 & 163674 & 89408 & 2.21 & 397.12 \\
\hline $\mathrm{T}_{10}$ & 9694 & 26.56 & 166998 & 92996 & 2.26 & 406.22 \\
\hline $\mathrm{SEm} \pm$ & 201 & 0.55 & 3541 & 3541 & 0.09 & 9.79 \\
\hline $\mathrm{CD}(0.05)$ & 566 & 1.55 & 9965 & 9965 & 0.26 & 27.99 \\
\hline
\end{tabular}

\section{System productivity and profitability}

The pooled data on system productivity and profitability was presented in Table 4. Results indicated that, the system profitability and system productivity were significantly influenced by different cropping systems. Significantly higher system productivity $(31.07 \mathrm{~kg} / \mathrm{ha} /$ year $)$ followed by $\mathrm{T}_{10}(26.56$ $\mathrm{kg} / \mathrm{ha} /$ year $)$ and $\mathrm{T}_{9}(25.99 \mathrm{~kg} / \mathrm{ha} /$ year $)$ and lowest being was observed in $\mathrm{T}_{3}(17.42 \mathrm{~kg} / \mathrm{ha} /$ year $)$. Further, the significantly higher system profitability (537.54 Rs/ha/day) was observed in $\mathrm{T}_{2}$ followed by $\mathrm{T}_{10}$ (406.22 Rs/ha/day) and $\mathrm{T} 1(406.12$ $\mathrm{Rs} / \mathrm{ha} /$ day). Whereas, least system profitability was recorded in $\mathrm{T}_{3}$ (289.72 $\mathrm{Rs} / \mathrm{ha} /$ day). These results corroborates the findings of Singh et al. (2007) ${ }^{[10]}$ who reported rice-pea-okra followed by rice-pea-onion as the most productive cropping sequence for eastern Uttar Pradesh, India. Mishra et al. (2007) [7] also reported higher productivity and profitability through inclusion of vegetables and pulses in rice-based cropping system. Walia et al. (2014) ${ }^{[14]}$ who reported that productivity in terms of REY and system productivity was highest for ricegreen pea-summer moongbean as compared to rice-wheat and all other crop sequences. In another study conducted at Australia reported that the choice of cropping systems had a significant impact on total grain production over a 3-year cropping cycle (i.e., grains produced by Year-1 plus Year-2 
plus Year-3 crops). Under dry conditions, the wheat-pulsedurum system produced $36.7 \%$ more grain yield and $61 \%$ more protein yield per 3-year cycle than the wheat-summer fallow-durum system (Yantai Gan et al., 2015) ${ }^{[13]}$.

\section{Economics of different systems}

Significantly higher pooled gross returns (Rs. 213355/ha), net returns (Rs. $142691 / \mathrm{ha}$ ) and B:C ratio (3.08) were observed in $T_{2}$ (rice followed by ridge gourd) compared to other cropping systems. The higher gross returns, net returns and $\mathrm{B}: \mathrm{C}$ ratio were owing to higher yields in the $\mathrm{T}_{2}$. It was followed by $T_{1}$ and $T_{9}$. Although rice followed by BPT 5204 rice $\left(T_{1}\right)$ was not superior to rice followed by ridgeguard in terms of REY (Table 4), however, it recorded significantly higher GR, NR and B:C ratio of Rs. 167881/ha, Rs. 90712/ha and 2.19 , respectively over all the three treatments of rice followed by other cropping systems with different rice varieties $\left(\mathrm{T}_{9}\right.$ and $\left.\mathrm{T}_{10}\right)$ and other treatment also. This was might be due to higher yield rice and market price. The significantly lower GR, NR and BC ratio was observed in $\mathrm{T}_{3}$. Kumar Alok et al. (2008) ${ }^{[6]}$ also reported that inclusion of vegetable crops in rice- based crop sequences improved the net returns.

\section{Conclusion}

The results indicated that, farmers can grow rice during kharif followed by ridge gourd or beans during rabi/summer to get higher productivity and income in Tunga Bhadra Command Area of Karnataka.

\section{Acknowledgement}

This research was conducted as part of the AICRP on IFS Project funded by IIFSR, Modipuram (UP) and University of Agricultural Sciences, Raichur for their kind support in implementation of the experiment.

\section{References}

1. Bastia DK, Garnayak LM, Barik T. Diversification of rice (Oryza sativa) - based cropping systems for higher productivity, resource-use efficiency and economics. Indian Journal of agronomy. 2008; 53(1):22-26.

2. Dwivedi BS, Shukla AK, Singh VK, Yadav RL. Results of participatory diagnosis of constraints and opportunities (PDCO) based trials from the state of Uttar Pradesh. In: Subba Rao, A., Srivastava, S. (Eds.), Development of Farmers' Resource-Based Integrated Plant Nutrient Supply Systems: Experience of a FAO-ICAR-IFFCO Collaborative Project and AICRP on Soil Test Crop Response Correlation. IISS, Bhopal, India, 2001, 50-75.

3. Gill MS, Ahlawat IPS. Crop diversification - its role towards sustainability and profitability. Indian Journal of Fertilizers. 2006; 2(9):125-138,

4. Gomez KA, Gomez AA. Statistical procedures for agricultural research (2 ed.). John Wiley and Sons, NewYork, 1984, 680.

5. Hegde DMS, Prakash Tiwari, and Rai M. Crop diversification in Indian Agriculture. Agricultural Situation in India. 2003, 351-354.

6. Kumar Alok Tripathi HP, Yadav RA, Yadav SR. Diversification of rice (Oryza sativa) - wheat (Triticum aestivum) cropping system for sustainable production in eastern Uttar Pradesh. Indian Journal of Agronomy. 2008; 53(1):18-21.

7. Mishra MM, Nanda SS, Mohanty M, Pradhan KC, Mishra SS. Crop diversification under rice based cropping system in western Orissa. In: Extended summaries 3rd National Symposium on Integrated Farming Systems, October 26-28, 2007 organized by Farming System and Development Association (Project Directorate for Cropping System Research, Modipuram, Meerut) at Agricultural Research Station, Durgapura, Jaipur, 2007.

8. Reddy BN, Suresh G. Crop diversification with oilseed crops formaximizing productivity, profitability and resource conservation. Indian Journal of Agronomy. 2009; 54(2):206-214.

9. Sharma AK, Thakur NP, Koushal Sanjay, Kachroo Dileep. Profitable and energy efficient rice-based cropping system under subtropical irrigated conditions of Jammu. In: Extended summaries 3rd National Symposium on Integrated Farming Systems, October 2628, 2007 organized by Farming System and Development Association (Project Directorate for Cropping System Research, Modipuram, Meerut) at Agricultural Research Station, Durgapura, Jaipur. 2007.

10. Singh P, Singh JP, Gill MS, Singh Y. Alternate cropping systems to sugarcane-ratoon-wheat in peri urban areas of Meerut. In: Extended summaries 3rd National Symposium on Integrated Farming Systems, October 2628, 2007, organized by Farming System and Development Association (Project Directorate for Cropping System Research, Modipuram, Meerut) at Agricultural Research Station, Durgapura, Jaipur, 2007.

11. Verma SP, Mudgal SC. Production potential and economics of fertilizer application as a resource constraints in maize-wheat crop sequences. Himachal $\mathbf{J}$ Agril. Res. 1983; 9(2):89-92.

12. Yadav JSP. Agricultural resource management in India: the challenges. Journal of Agricultural Water Management. 2002; 1(1):61-69.

13. Yantai Gan, Chantal Hamel, John Donovan TO, Herb Cutforth, Robert Zentner $\mathrm{P}$, Con Campbell A et al. Diversifying crop rotationswith pulses enhances system productivity in www.nature.com/scientificreports, 2015.

14. Walia SS, Singh Satpal Gill RS, Aulakh CS, Kaur Navdeep. Production potential and economic analysis of different rice-based cropping systems in north-west India. Research on Crops. 2014; 15(3):539-542. 